\title{
The haemochromatotic human pancreas: a quantitative immunohistochemical and ultrastructural study
}

\author{
J. Rahier, S. Loozen, R. M. Goebbels and M. Abrahem \\ Department of Pathology, School of Medicine, University of Louvain, Louvain, Brussels, Belgium
}

\begin{abstract}
Summary. Insulin, glucagon, somatostatin and pancreatic polypeptide cells were quantified after immunoperoxidase staining in sections of pancreases obtained from nine control subjects and seven diabetic patients with primary or secondary iron overload. One was normoglycaemic, two had glucose intolerance and four presented insulin-requiring diabetes. The whole pancreas was studied, taking into account the heterogeneous distribution of the endocrine cells. In the diabetic patients, the weight of the pancreas tended to be lower. Iron overload predominated in the exocrine tissue, whereas in islets iron concentration was quite variable from case to case. At the Haemalun-Eosine staining the histological appearance of the islets was normal, their shape and size being unchanged; amyloid deposits were absent, as were atrophic islets. Immunoperoxidase staining revealed a severe reduction in the number of immunoreactive $B$ cells in the four diabetic patients. The mass of immunoreactive B cells was calculated from their volume
\end{abstract}

density and from the weight of each lobe of the pancreas. It averaged $950 \mathrm{mg}$ in control subjects, $1580 \mathrm{mg}$ in the normoglycaemic patient, $1010 \mathrm{mg}$ in patients with glucose intolerance and $180 \mathrm{mg}$ in insulin-requiring diabetic patients. The electron microscopic examination, performed in four cases, revealed that the iron deposits were restricted to $\mathrm{B}$ cells and associated with progressive loss of their endocrine granules. The study shows that the pancreatic islet abnormalities in iron overloaded diabetic patients are completely different from those of Type 1 (insulin-dependent) and Type 2 (non-insulin-dependent) diabetic patients. This constitutes a further argument for a specific role of iron in the pathogeny of diabetes in haemochromatotic patients.

Key words: Endocrine pancreas, haemochromatosis, immunocytochemistry, ultrastructure, diabetes.
Though the frequent association of iron overload and diabetes has long been recognized [1, 2], the exact nature of this relationship remains controversial. It is still unclear whether the diabetic disease is inherited or at least related to familial factors, or if the iron overload has a direct diabetogenic role. Epidemiological studies have led to opposite conclusions [3-7]. However, large prospective studies by Simon at al. $[8,9]$ indicate that the frequency of diabetes in relatives of haemochromatotic patients bears no relation to the carbohydrate regulation of these patients. These results suggest that the tendency to develop diabetes is not genetically inherited in these patients, but that iron overload is diabetogenic per se. The frequency of diabetes observed in secondary iron overload, in experimental animal models [10], in the Bantu population [11] and in patients suffering from sidero-achrestic anaemia or from thalassaemia $[12,13]$ reinforces this hypothesis. In the latter group, glucose intolerance correlates significantly with the number of received transfusions. However, a higher prevalence of diabetes in relatives of thalassaemic diabetic patients [13] suggests that associated ground factors contribute to precipitation of the disease by iron overload.

Only a few recently reviewed studies [14] have analysed the morphological consequences of iron overload on the endocrine pancreas. Early reports $[15,16]$ indicated that the iron deposits are located in B cells, but suggested [17] that the destruction of B cells does not result from these iron deposits, since diabetes could be observed in cases with only minor iron overload in the islets.

The aim of the present study was to (1) investigate, by quantitative immunochemical methods and electron microscopy, the specific characteristics of the islets of Langerhans in diabetes associated with iron surcharge; and (2) determine whether islet morphology of this secondary diabetes is closer to that of diabetes of Type 1 or Type 2, or whether it corresponds to that of a third type.

\section{Materials and methods}

Pancreases were obtained within $6 \mathrm{~h}$ after death from seven male diabetic patients with hepatic and pancreatic iron surcharge and from nine age-matched male control subjects. These latter died from diseases not known to affect the pancreas and did not exhibit glucose intolerance. Clinical data of patients with iron overload are given in Table 1.

Familial history of diabetes was reported in none of the seven cases and could even be ruled out by systematic interrogation.

After careful dissection, the whole pancreas was cut in parallel slices $2-3 \mathrm{~mm}$ thick. All slices were numbered, weighed, fixed in Bouin-Allen's fluid and embedded in paraffin. The limits of the lobe rich in pancreatic polypeptide (PP) cells $[18,19]$ were delineated and the weight of each lobe was calculated as previously reported [20]. Specimens were then taken in the posterior part of the head (lobe rich in PP-cells), in the anterior part of the head, in the body and in the tail. 
Table 1.

\begin{tabular}{|c|c|c|c|c|c|c|c|c|}
\hline $\begin{array}{l}\text { Patient } \\
\text { no. }\end{array}$ & Age & Diagnosis & Cause of death & $\begin{array}{l}\text { Plasma ferritin } \\
\text { level } \\
(n<300 \mathrm{mg} / \mathrm{ml})\end{array}$ & $\begin{array}{l}\text { Glucose } \\
\text { homeostasis }\end{array}$ & \multicolumn{2}{|l|}{ Treatment } & $\begin{array}{l}\text { Liver } \\
\text { iron } \\
\text { overload }\end{array}$ \\
\hline 3 & 60 & $\begin{array}{l}\text { Macronodular cirrhosis } \\
\text { Secondary haemochro- } \\
\text { matosis } \\
\text { Hepatitis B }\end{array}$ & $\begin{array}{l}\text { Hepatic insuffi- } \\
\text { ciency }\end{array}$ & 705 & $\begin{array}{l}\text { Fasting blood } \\
\text { glucose } 15 \mathrm{mmol} / \mathrm{I}\end{array}$ & - & - & Massive \\
\hline 5 & 50 & $\begin{array}{l}\text { Micronodular cirrhosis } \\
\text { Secondary haemochro- } \\
\text { matosis } \\
\text { Alcoholism }\end{array}$ & $\begin{array}{l}\text { Hepatic insuffi- } \\
\text { ciency }\end{array}$ & 1490 & $\begin{array}{l}\text { Insulin requir- } \\
\text { ing diabetes }\end{array}$ & $\begin{array}{l}\text { Insulin } \\
(5 \mathrm{~m})\end{array}$ & & Massive \\
\hline 6 & 70 & $\begin{array}{l}\text { Micronodular cirrhosis } \\
\text { secondary haemochro- } \\
\text { matosis } \\
\text { Sideroachrestic anemia }\end{array}$ & $\begin{array}{l}\text { Oesophageal va- } \\
\text { rices bleeding }\end{array}$ & 1520 & $\begin{array}{l}\text { Insulin requir- } \\
\text { ing diabetes }\end{array}$ & $\begin{array}{l}\text { Sulfonyl- } \\
\text { urea }(6 y) \\
\text { Insulin } \\
(2 y)\end{array}$ & - & Massive \\
\hline 7 & 62 & $\begin{array}{l}\text { Micronodular cirrhosis } \\
\text { Primary haemochrom- } \\
\text { atosis }\end{array}$ & Hepatoma & $\begin{array}{l}490 \\
\text { (under iron de- } \\
\text { privative treat- } \\
\text { ment) }\end{array}$ & $\begin{array}{l}\text { Insulin requir- } \\
\text { ing diabetes }\end{array}$ & $\begin{array}{l}\text { Insulin } \\
(14 \mathrm{y})\end{array}$ & $\begin{array}{l}\text { Desferox- } \\
\text { amine } \\
\text { Phlebotomy }\end{array}$ & Massive \\
\hline
\end{tabular}

Table 2.

\begin{tabular}{llll}
\hline $\begin{array}{l}\text { Patient } \\
\text { no. }\end{array}$ & $\begin{array}{l}\text { Pancreatic } \\
\text { weight }(\mathrm{g})\end{array}$ & $\begin{array}{l}\text { PP-rich lobe } \\
\text { relative } \\
\text { weight }(\%)\end{array}$ & $\begin{array}{l}\text { Mesenchymal } \\
\text { fraction (\%) }\end{array}$ \\
\hline 1 & 120 & 11.2 & 28.8 \\
2 & 138 & 13.2 & 33.8 \\
3 & 46 & 16.2 & 28.2 \\
4 & 76 & 13.5 & 22.9 \\
5 & 39 & 12.2 & 43.4 \\
6 & 34 & 20.3 & 47.3 \\
7 & 34 & 15.7 & 34.8 \\
Control & $87 \pm 32$ & $9.7 \pm 2.7$ & $19.2 \pm 6.1$ \\
subjects & & & \\
$(n=9)$ & & & \\
\hline
\end{tabular}

From each of them, six consecutive sections were stained by Haemalun Eosine, Grimelius [21] and the PAP technique of Sternberger [22] with guinea-pig anti-insulin serum (Dr. P.H.Wright, Indianapolis, Ind, USA), rabbit anti-glucagon serum (Dr. A.Like, Worcester, Mass, USA), rabbit anti-somatostatin serum (Dr. W. Gepts, Brussels, Belgium) and rabbit anti-pancreatic polypeptide serum (Dr. R. E. Chance, Indianapolis, Ind, USA) at dilutions of $1 / 3000,1 / 4000,1 / 10000$ and $1 / 40000$ respectively. Iron deposits were simultaneously demonstrated by the Prussian blue reaction [23]. The specificity of each reac- tion was assessed by absorption of the antiserum with the corresponding antigen. The volume density of each endocrine cell type and that of mesenchymal tissue was determined by the point counting method of Chalkley [24] as previously reported [20]. From the volume density of each endocrine cell type measured in the two lobes of the pancreas, the proportion of mesenchymal tissue and the absolute weight of this two lobes, the total mass of the different endocrine cells was calculated.

Small specimens were also taken in the corpus from cases $3,5,6$ and 7, fixed in glutaraldehyde solution, postfixed in osmium and embedded in Epon 812 for electron microscopy.

\section{Statistical analysis}

Results are presented as means $\pm \mathrm{SD}$. The significance of differences between means was assessed by the Wilcoxon rank-sum test [25]. A $p$ value of $<0.05$ was considered statistically significant.

\section{Results}

\section{Macroscopy}

Its firm consistency and its chamois-brown colour, after removal of the peripancreatic fat, give the haemochro-

Fig. 1 A-D. Double staining technique of pancreatic tissue: Prussian blue method for iron detection (in blue) and peroxidase antiperoxidase technique (in brown) with anti-insulin serum (A-C) or Grimelius technique (dark brown) (D). A Numerous B cells containing iron (Prussian blue and anti-insulin immunoperoxidase). (Case 2) B-C Marked decrease (case 4) or disappearance (case 7) of both insulin immunoreactivity and iron deposits in the islets. D Iron deposits predominate in endocrine cells from the central part of the islets. Grimelius positive cells (A and PP cells) are devoid of iron (Case 2) 


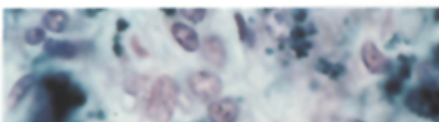

- $20.02 \pi$

AX. \%

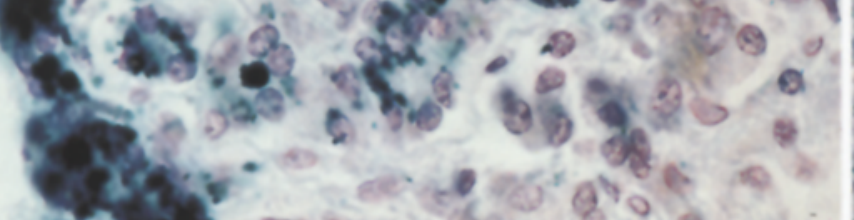

10 के
(3. जo

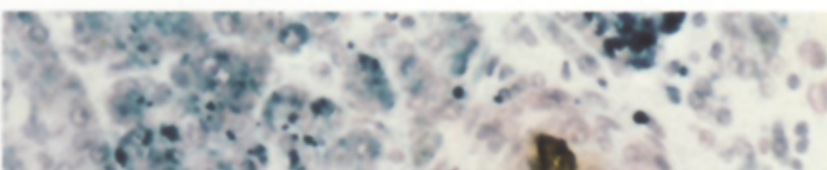

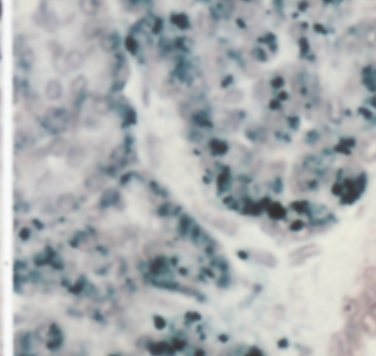

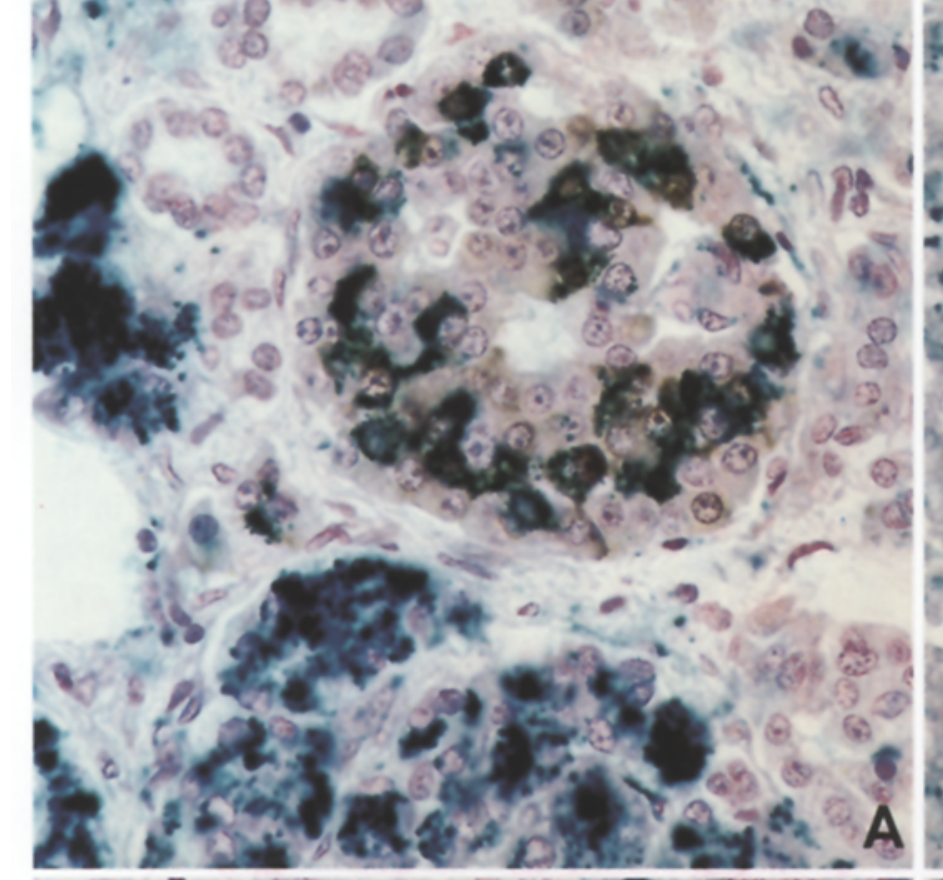
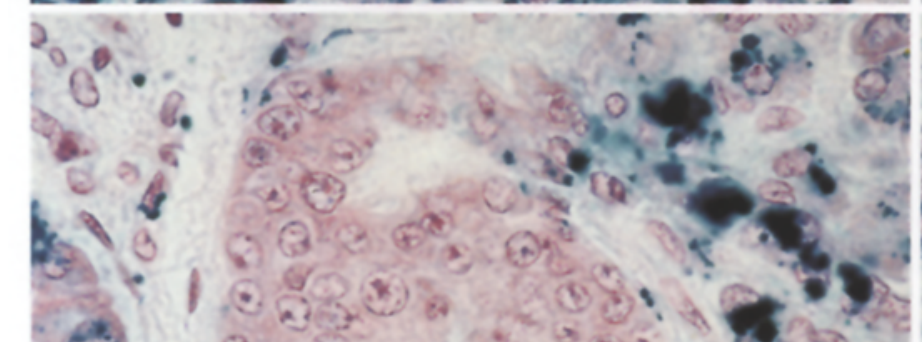

2.

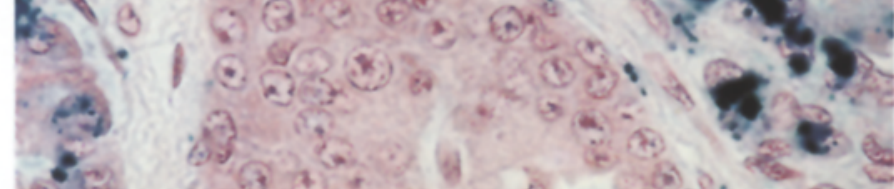

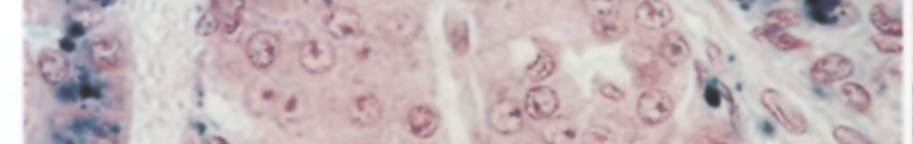

खोi

$=2,1.0^{2}$,

$\operatorname{lat}_{0} \cdot 10$

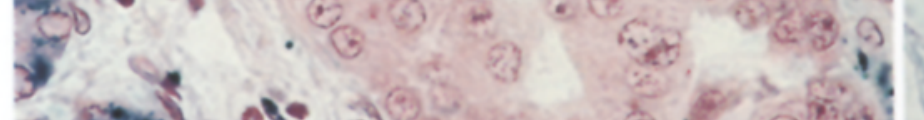

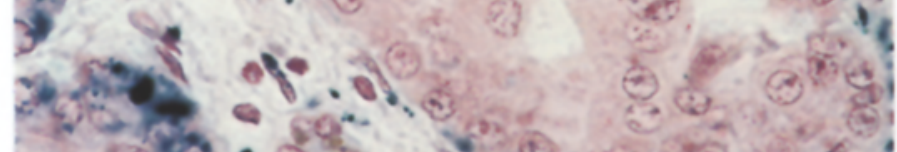

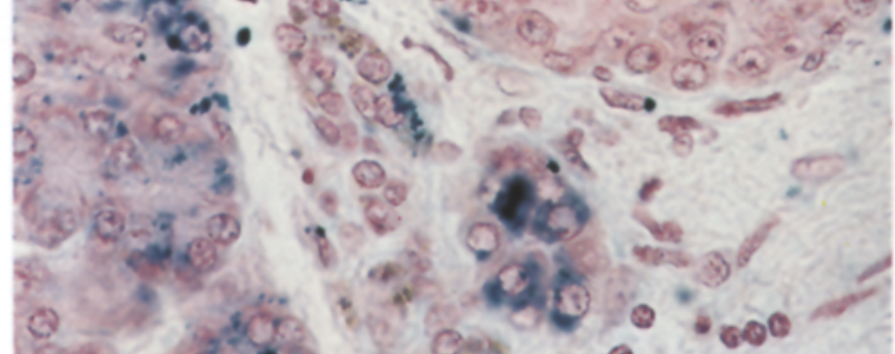

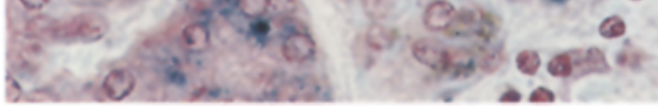

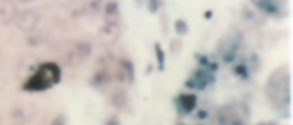

$y^{4}+0_{2}+\vec{k}_{1}=$

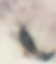

- 41,2 is

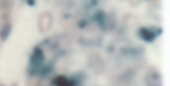
4. $8, \pi$

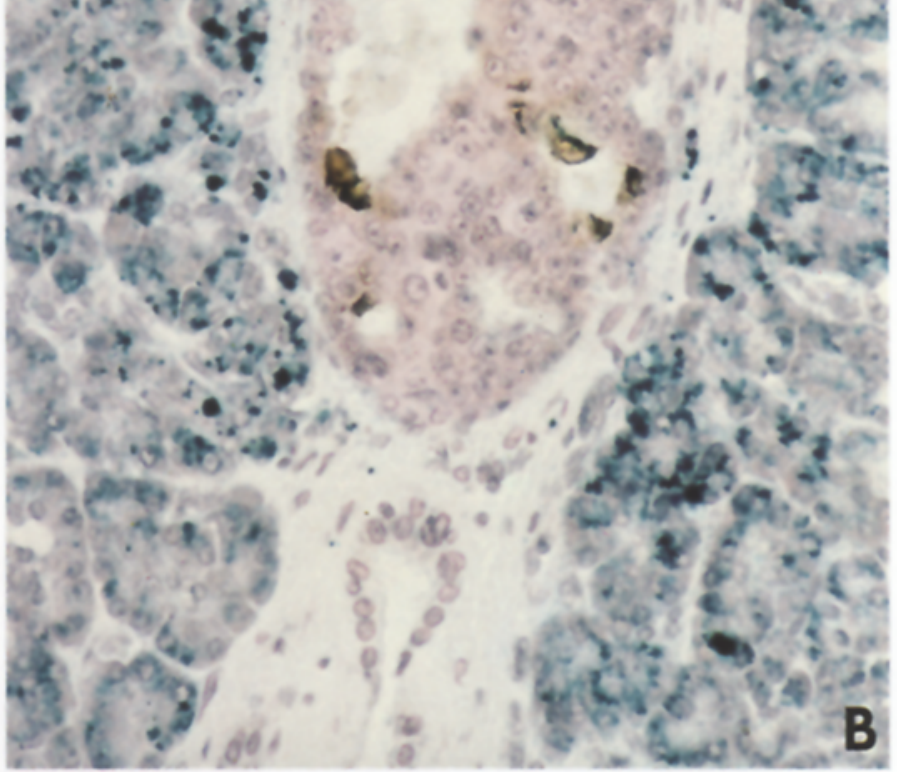

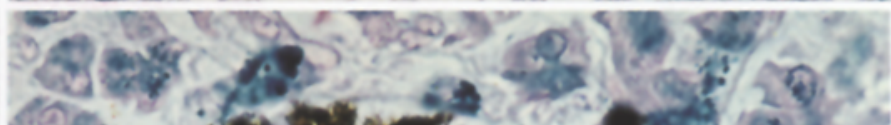

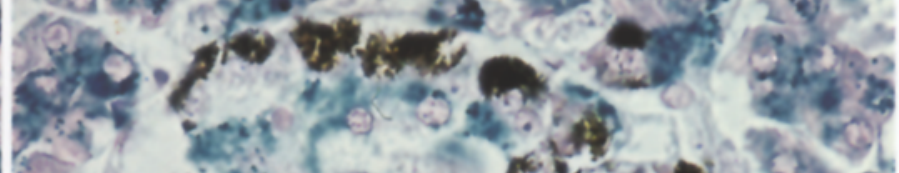

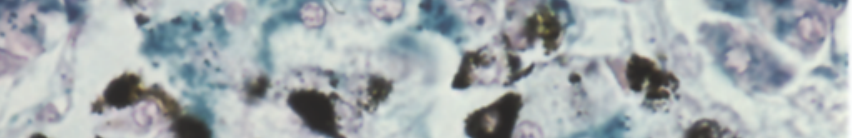

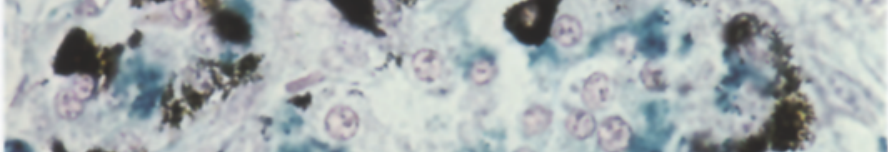

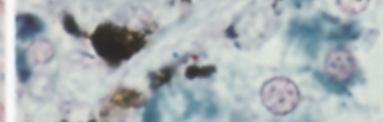

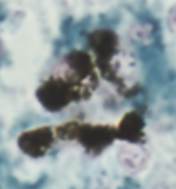

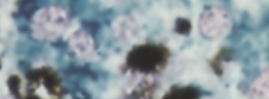
18.

है

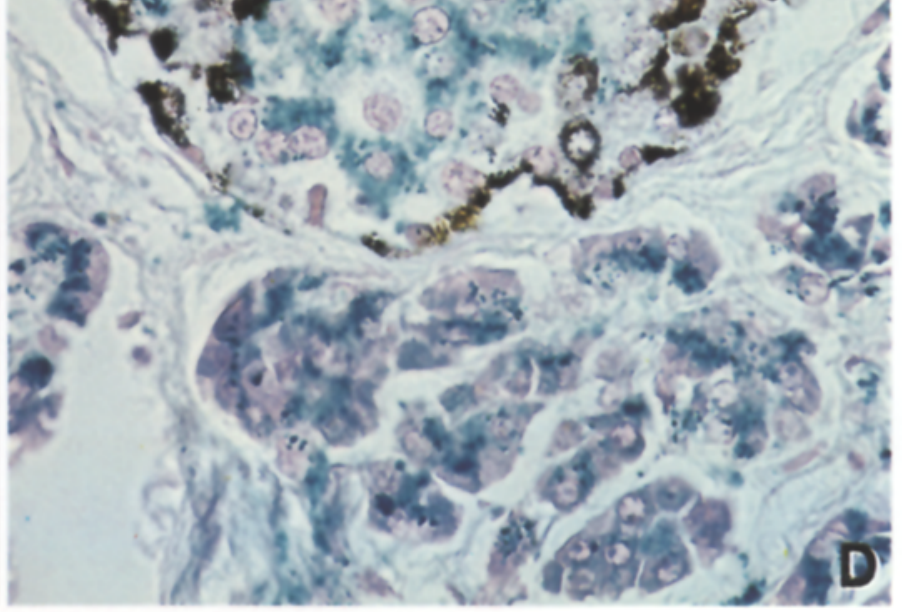




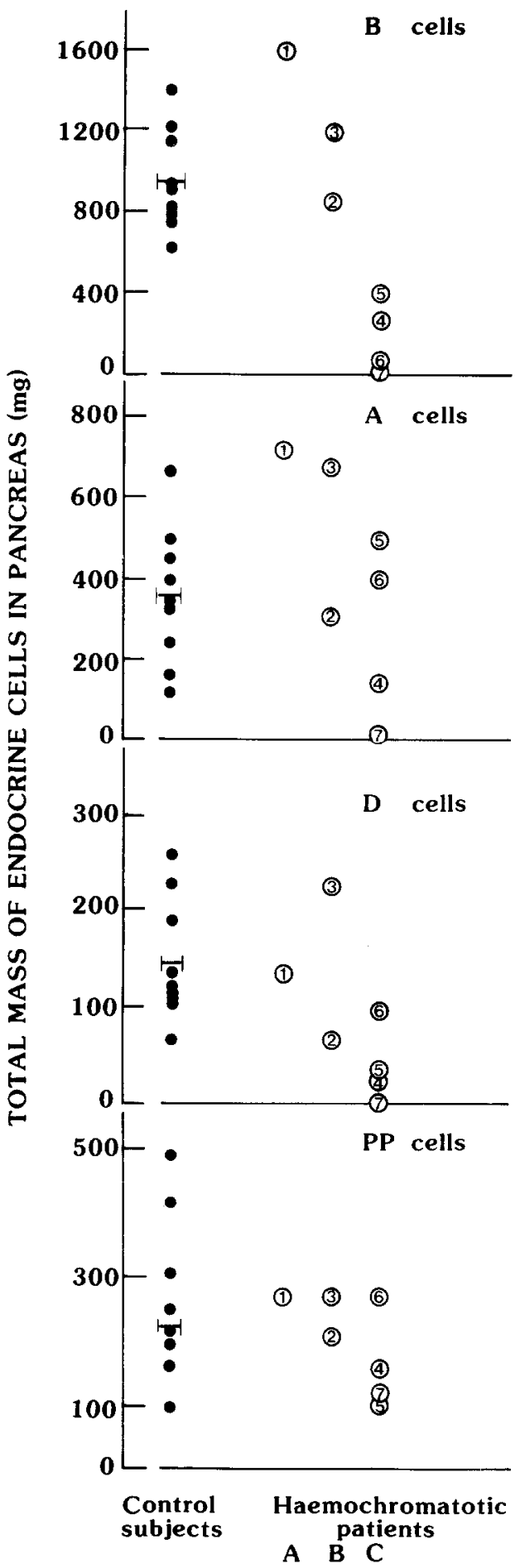

Fig. 2 A-C. Estimated total mass of each endocrine cell type in the pancreas of control and normoglycaemic(A), gluco-intolerant(B) and insulin-requiring diabetic haemochromatotic patients (C)

matotic pancreas a particular and typical aspect. As shown in Table 2, the weight of the pancreas was clearly lower in insulin-requiring diabetic haemochromatotic patients (nos.4-7) than in the normoglycaemic haemochromatotic patient (no.1), in whom it remained within the normal values. The relative weight of the lobe rich in PP cells was increased in these diabetic patients $(p<0.05)$, as reported in classical Type 1 and 2 diabetic patients [26].

\section{Conventional microscopy}

The mesenchymal component of the gland, consisting of fat or fibrous tissue, was much more abundant than in controls (Table 2). As classically described [27], iron deposits predominated in exocrine tissue and in macrophages of the connective tissue and was less frequent in islets, whatever the etiology of iron overload. It is noteworthy, however, that iron overload was more important in the islets of normoglycaemic and non-insulin-dependent diabetic haemochromatotic patients (nos.1-3) than in those of insulin-dependent diabetic haemochromatotic patients (nos.4-7). The shape and size of the islets were unchanged in haemochromatotic patients; their number seemed to be normal in all cases but one (no.7), in whom they were less numerous. However, even in this case atrophic irregular islets, typical of insulin-dependent diabetic patients, were not observed. Moreover, amyloid deposits, frequently detected in islets of non-insulin-dependent diabetic patients, were absent from islets of haemochromatotic diabetic patients.

\section{Quantitative immunocytochemistry}

Immunocytochemical techniques disclosed several peculiarities of the islets of haemochromatotic patients which had escaped detection after haemalun-eosin staining. Iron pigments were found almost only in immunoreactive B cells; A, D and PP cells were devoid of iron deposits, as were most of the non-immunoreactive cells of the islets. It is immediately observed that marked differences may exist in the number of immunoreactive B cells from case to case (Fig.1). Although not quantified by morphometry, a positive correlation seemed to exist between the iron overload and the number of immunoreactive B cells. The total mass of endocrine tissue average $1667 \mathrm{mg}$ (range:1064-2426) in control subjects, $2696 \mathrm{mg}$ in the normoglycaemic haemochromatotic patient (no.1), and 2347 and 1428 in the two haemochromatotic patients with glucose intolerance (no. 2 and 3). On the other hand, it was markedly decreased (1018-138) in the four insulin-requiring diabetic haemochromatotic patients (nos. 4-7). The calculated mass of each endocrine cell type in the pancreases of controls and haemochromatotic patients is shown by Fig. 2. In insulin-requiring diabetic haemochromatotic patients the mass of immunoreactive $B$ cells was markedly lowered. The mass of A cells and that of D cells was either decreased or normal, and that of PP cells was unchanged. In the two haemochromatotic patients with glucose intolerance the mass of $B, A, D$ and PP cells remained within the normal values. In the normoglycaemic patient, the mass of $B$ and A cells was higher than in controls, whereas that of $D$ and PP cells was within normal values. The volume density of all immunodetected 
cells in the islets (sum of A, B, D and PP) was clearly lower than the volume density of islet cells measured after haemalun-eosin staining in insulin-requiring haemochromatotic patients (Fig. 3). Such was not the case in control subjects or in other haemochromatotic patients, in whom the ratio was close to unity. This indicates that certain islet cells are not detected by immuno-

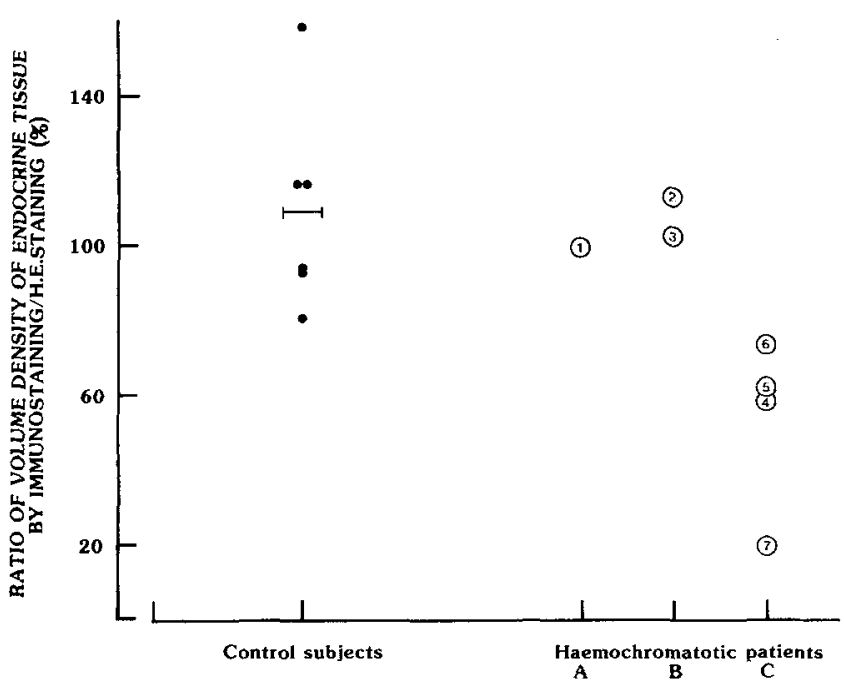

Fig. 3. Ratio of the volume density of endocrine tissue estimated on immunostained slices on Haemalun Eosin staining in the pancreas of control and normoglycaemic(A), gluco-intolerant (B) and insulin-requiring diabetic haemochromatotic patients (C) cytochemistry in the group of diabetic haemochromatotic patients.

\section{Ultrastructural analysis}

Ultrastructural analysis of the islets was performed in one patient with glucose intolerance (no.3) and in three insulin-requiring haemochromatotic patients (nos.5-7). In patient 3 , a high content in typical $\beta$-granules allowed easy recognition of B cells (Fig. 4 a), the proportion of which appears normal. Iron overload was evident from the presence of numerous lysosomes containing haemosiderin deposits. The amount of haemosiderin pigments was quite variable from cell to cell. The rough endoplasmic reticulum (RER) was well preserved, its sheets sometimes being undoubled. No degenerative changes occurred, and the rate of granulation remained similar to that of controls, with most of the granules being of the mature crystalline type. A, D and PP cells did not show ultrastructural abnormalities and, in particular, were devoid of haemosiderin deposits. In patient $5, \mathrm{~B}$ cells no longer constituted the predominant population of the islets, non-B cells being the most numerous. Lipofuchsin inclusions and degenerative vacuoles were observed in B cells. Haemosiderin deposits were restricted to B cells. As iron overload, the rate of granulation was quite variable from cell to cell but was, in general, lower than in normal B cells

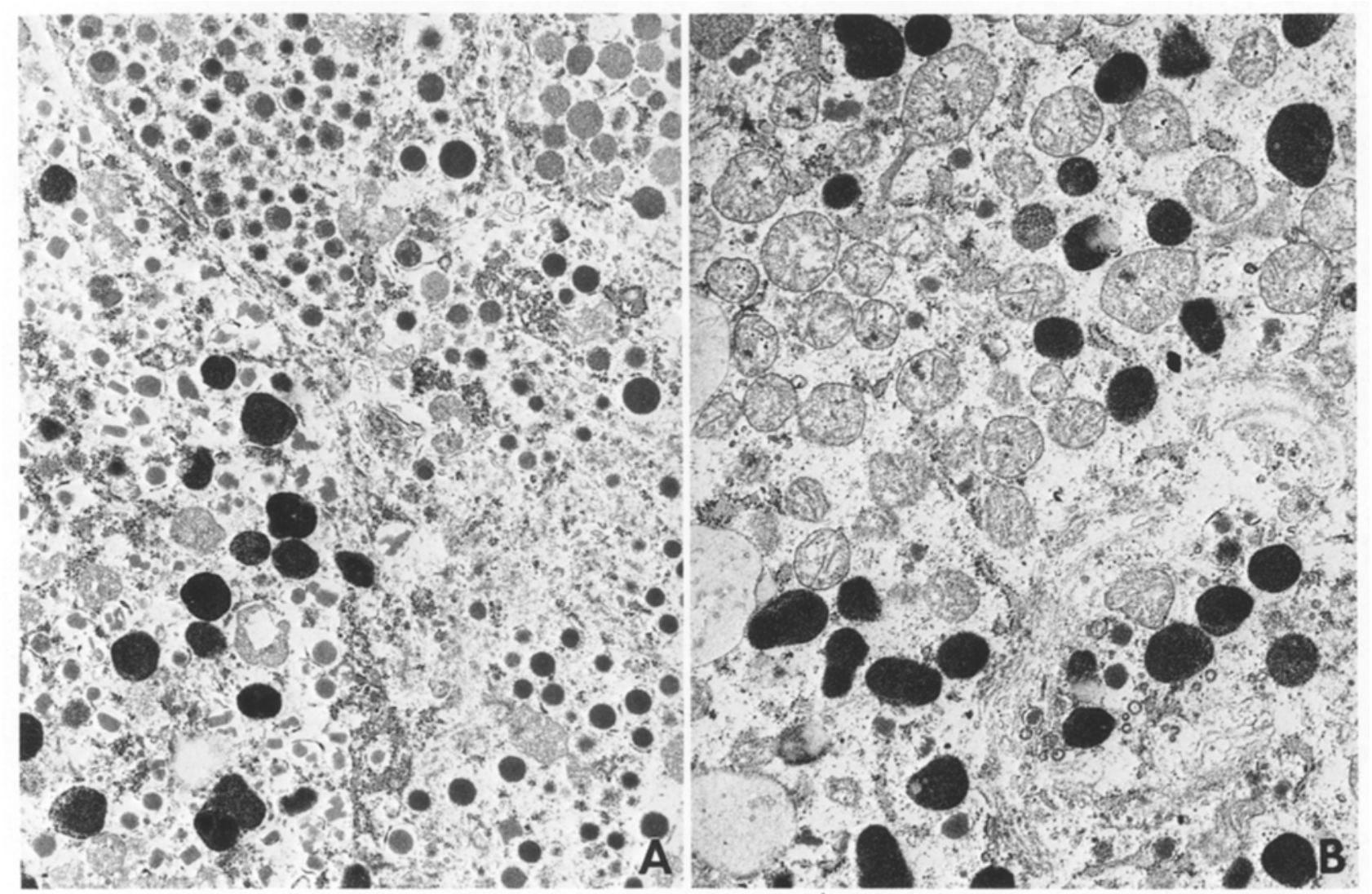

Fig.4. A Electron micrograph of an islet from case 3. Iron deposits are restricted to B cells. Numerous typical $\beta$-granules are still present, but their electron density is weaker than in normal B cells. B Electron micrograph of a B cell from case 5 . Only few granules are detected in the cytoplasm 


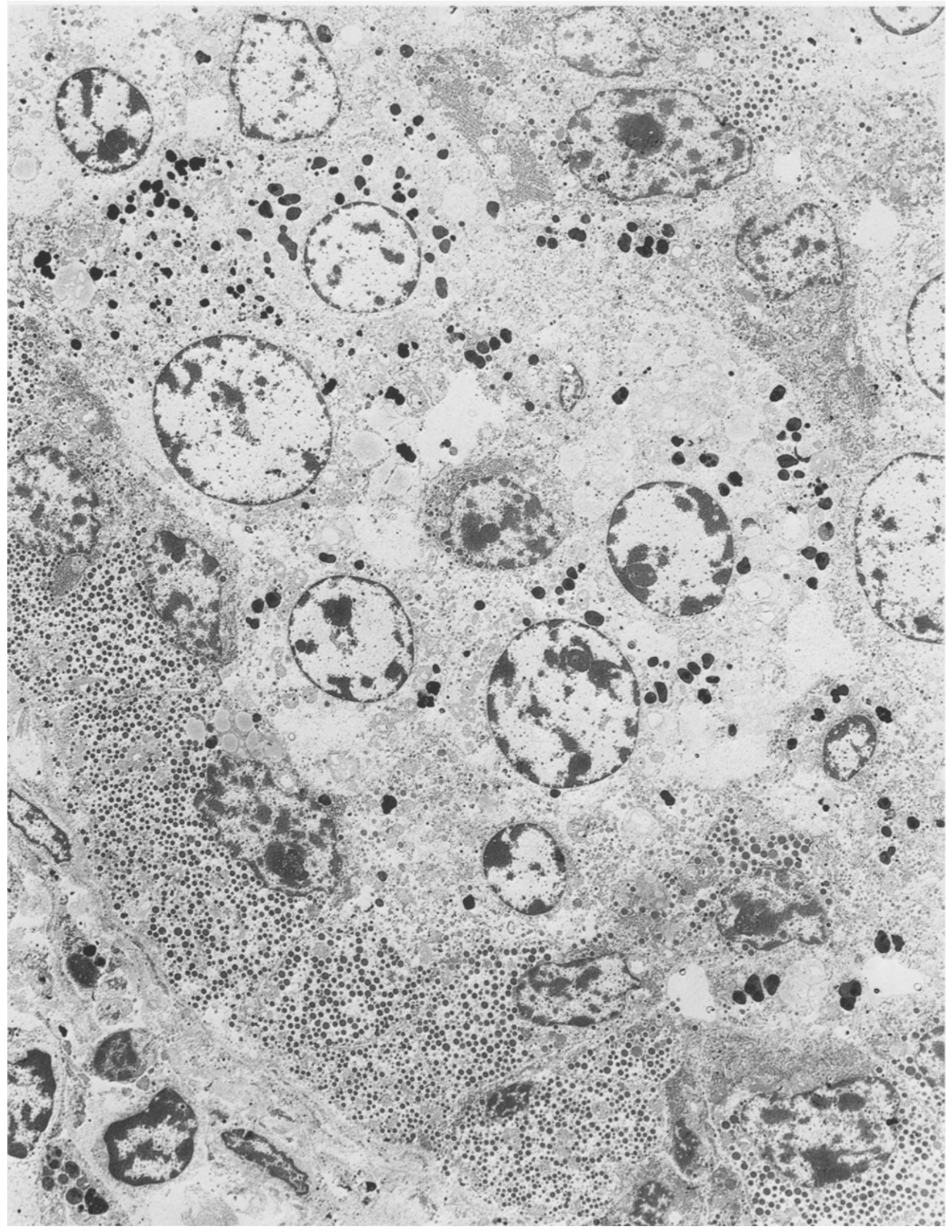

Fig.5. Low magnification of an islet from case 5. A and D cells remain normally granulated and devoid of haemosiderin. B cells show a major iron surcharge and a clear decrease in the number of insulin granules 
(Fig. 4b). Pictures suggest that the decrease in $\beta$-granules number correlates with the importance of the iron overload. However, haemosiderin pigments were exclusively observed in still granulated B cells. Non-granulated or poorly granulated cells with non-typical granules were seen in islets. These scarce granules were of small size and electron dense. Most often, these cells were devoid of iron or contained only a small amount. The ultrastructural aspect of A, D and PP cells was not particular. Islets were also observed to be formed in close contact with exocrine ducts, sometimes incorporating ductular cells within the endocrine structure. In patients 6 and particularly 7, islets were rare and B cells infrequent. These cells were difficult to recognize, from the low number and weak density of their granules, in comparison with non- $\beta$-granules (Fig. 5). Their cytoplasms were clear, with vacuoles or white spaces. As in the other cases, iron was restricted to B cells and its amount was quite variable. Particular cells were also encountered with empty granules or granules containing only finely granular material. They were devoid of iron. These cells were located in islets, but no formal morphological argument allows their endocrine nature to be ascertained. Multivesicular bodies and undoubling of the RER sheets were observed, not only in some B cells, but also in other endocrine cells.

\section{Discussion}

The seven patients included in this series were selected on the basis of iron deposits in the liver, mostly in parenchymal and ductular cells, confirmed in most of the cases by a clinical diagnosis of iron overload (high seric ferritin level and Iron Binding Capacity). The etiology of the iron overload (primary or secondary) was not taken into account.

Several arguments support the hypothesis of a specific role of iron overload in the development of diabetes in haemochromatotic patients. First, the high frequency of diabetes (or glucose intolerance) associated with haemochromatosis ( $6 / 7$ in this series) cannot be fortuitous. Second, none of the patients became diabetic before an iron overload in the liver was detected. Third, the morphological aspect of the pancreas was similar in the primary and secondary types of the disease. Fourth, our study clearly shows that the islet morphology in diabetes associated with haemochromatosis differs from that of the other types of diabetes.

The normal size and round shape of the islets in haemochromatotic patients make them indeed totally different from the pseudoatrophic irregular islets consistently observed in chronic Type 1 diabetic patients $[20,28]$. Moreover, the mass of immunoreactive B cells, though very low in some insulin-requiring haemochromatotic patients, is still much higher than in Type 1 diabetic patients. Several features also make these islets distinguishable from those of Type 2 diabetic patients. First, they never contain amyloid deposits. Second, the mass of immunoreactive $\mathrm{B}$ cells in the haemochromatotic insulin-requiring diabetic patients is markedly lower than in Type 2 diabetic patients [20], even when these latter require insulin treatment. Third, apparently normal islets, where only three or four B cells can be detected by immunostaining, have never been observed in pancreases of Type 2 diabetic patients.

A very good correlation exists between the morphometrical estimation of the B-cell mass by immunochemistry and the clinical data. The patient with a B-cell mass higher than in control subjects does not show any glucose intolerance, in spite of an important iron overload. The persistence of normoglycaemia in this case could be explained by an adaptative hyperplasia of the cells, balancing a possible functional deficiency. The two patients with glucose intolerance display a relatively normal mass of B cells, suggesting that this glucose intolerance has to be related to the existence of a functional B-cell deficiency. Lastly, in the four insulin-requiring diabetic patients, the mass of immunoreactive $B$ cells is markedly decreased, explaining the clinical symptomatology. The exact evaluation of the decrease in the B-cell mass in the four insulin-requiring diabetic patients is, however, difficult to ascertain from immunohistochemical quantitative study alone since, as proposed previously [31], a marked decrease or a lack of granulation may lead to an underestimation by these techniques. This is the reason to compare VV of insular cells on HES stained sections to the summation of the VV for each immunodetected endocrine cell type. From this comparison, it becomes evident that not only a decrease in the real mass of the endocrine cells explains the low endocrine cell mass measured, at least in cases with a long duration of diabetes, but that an underestimation of endocrine cells also is responsible for it, probably due to a low hormonal content. Electron microscopy reinforces this hypothesis, since numerous poorly granulated B cells are present in these islets; the observation that $A$ and $D$ cells are still well granulated allows us to conclude that the underestimation related to degranulation is restricted to B cells. Non-granulated cells are also encountered in the islets of insulin-requiring haemochromatotic patients. The real significance of these cells is not clear; they may correspond to old $B$ cells in which insulin synthesis has been interrupted and iron deposit excluded. They could also be new immature endocrine cells of the B- or non-B-cell line, not yet differentiated or unable to differentiate in this particular context. The presence of very small amounts of iron in a few of these cells may, however, constitute an argument to think that they belong to the B-cell line.

It remains difficult to ascertain whether the iron overload is the only factor responsible for the development of diabetes or whether other elements may interfere with the importance of the glucose intolerance, with its insulin-dependent character, or with the rapidity of its appearance. Thus, no correlation seems to exist between the suspected duration of iron overload and the advent of diabetes. However, the importance of iron 
overload in the liver, as in the pancreas, does also not correlate with the duration of iron overload. This apparent discrepancy can be explained by a different velocity of iron overloading $[29,30]$.

Electron microscopic analysis and iron detection by the Prussian blue method combined with immunocytochemistry, formally demonstrate that iron overload is restricted to $B$ cells. The reason for this restriction remains unknown. The persistence of a normal or high glucagon secretion $[32,33]$ in these patients is in agreement with our observation, but does not allow us to conclude, as previously [34], that the islets of Langerhans are normal in iron overloaded patients.

In conclusion, immunocytochemical quantitative studies and electron microscopic analysis demonstrate that the islets of Langerhans in iron overloaded patients do not share the morphological characteristics of islets of Type 1 nor Type 2 diabetic patients, but show a particular aspect related to the existence of iron surcharge. It is evident that haemochromatotic diabetes and Type 1 diabetes are completely different entities. Our study strongly suggests that such is also the case for haemochromatotic diabetes and Type 2 diabetes. However, the formal proof of this proposal requires elucidation of the pathogenesis of Type 2 diabetes.

Acknowledgments. The authors thank Dr. J.C. Henquin for advice and critical reading of the manuscript and $\mathrm{E}$. Rausch for careful typewriting. This study was supported by grant no.3.456081 of the FRSM, Brussels.

\section{References}

1. Trousseau A (1865) Glucosurie: diabète sucré. Clinique Médicale de l'Hôtel Dieu de Paris, 2: 663, Baillere, Paris

2. Troisier M (1871) Diabète surcré. Bull Soc Anat (Paris) 16: 231-235

3. Bastenie PA, Pirart J (1963) Hémochromatose et diabète. In: Les hémochromatoses. XXXIVe Congrès Français de Médecine. Masson, Paris, p 399

4. Balcerzak SP, Mitz DH, Westerman MP (1968) Diabetes mellitus and idiopathic hemochromatosis. Am J Med Sci 255: 53-62

5. Dymock IW, Cassar J, Pyke DA, Oakley WG, Williams R (1972) Observations on the pathogenesis, complications and treatment of diabetes in 115 cases of haemochromatosis. Am $\mathbf{J}$ Med 52: 203-210

6. Bierens de Haan B, Scherrer JR, Stauffacher W, Pometta D (1973) Iron excess, early glucose intolerance and impaired insulin secretion in idiopathic haemochromatosis. Eur J Clin Invest 3:179-187

7. Saddi R, Feingold J (1974) Idiopathic haemochromatosis and diabetes mellitus. Clin Genet 5:242-247

8. Simon M, Alexandre JL, Scordia C, Hespel JP, Bourel M (1976) Diabète de l'hémochromatose et diabète commun. Résultats d'une étude prospective de 97 familles d'hémochromatose idiopathique. Diabete Metab 2: 113-118

9. Simon M, Alexandre JL, Fauchet R, Genetet N, Scordia C, Jollant M, Hespel JP, Bourel M (1978) Le diabète de l'hémochromatose idiopathique n'est pas favorisé (sauf à titre fortuit) par l'intermédiaire diabétique. In: Journées Annuelles de Diabétologie de l'Hôtel Dieu. Flammarion Paris, pp 33-43

10. Awai M, Narasaki M, Yamanoi Y, Seno S (1979) Induction of diabetes in animals by parenteral administration of ferric nitrilotriacetate. Am J Pathol 95: 663-673

11. Isaacson C, Seftel SC, Keeley KJ, Bothwell TH (1961) Siderosis in the Bantu: The relationship between iron overload and cirrhosis. J Lab Clin Med 58: 845-853

12. Costin G, Kogut MD, Hyman C, Ortega JA (1977) Carbohydrate metabolism and pancreatic islet-cell function in thalassemia major. Diabetes 26: 230-240

13. Saudek CD, Hermm RM, Peterson CM (1977) Abnormal glucose tolerance in beta-thalassemia major. Metabolism 26: 43-52

14. Gepts W (1981) Islet changes in human diabetes. In: Cooperstein SJ, Dudley Watkins (eds) The islets of Langerhans: biochemistry, physiology and pathology. Academic, pp 321-356

15. Hartroft WS (1956) Islet pathology in diabetes. Diabetes 5:98-104

16. Mac Gavran MH, Hartroft WS (1956) The predilection of pancreatic beta cells for pigment deposition in hemochromatosis and hemosiderosis. Am J Pathol 32: 361 (Abstract)

17. Bell ET (1955) The relation of portal cirrhosis to hemochromatosis and to diabetes mellitus. Diabetes 4: 435-446

18. Malaisse-Lagae F, Stefan Y, Cox J, Perrelet A, Orci L (1979) Identification of a lobe in the adult human pancreas rich in pancreatic polypeptide. Diabetologia 17:361-365

19. Rahier J, Wallon J, Gepts W, Haot J (1979) Localization of pancreatic polypeptide cells in a limited lobe of the human neonate pancreas: remnant of the ventral primordium? Cell Tissue Res 200: 359-366

20. Rahier J, Goebbels RM, Henquin JC (1983) Cellular composition of the human diabetic pancreas. Diabetologia 24: 366-371

21. Grimelius L (1968) A silver nitrate stain for alpha-2 cells in human pancreatic islets. Acta Soc Med Ups 73: 243-270

22. Sternberger LR (1979) Immunocytochemistry, 2nd edn. John Wiley, New York

23. Schmidt MB (1889) Über die Verwandtschaft der hämatogenen und autochtbonen Pigmente und deren Stellung zum sogenannten Hämosiderin. Virchows Arch Pathol Anat Physiol 115:397-459

24. Chalkley HW (1943) Method for the quantitative morphologic analysis of tissues. J Natl Cancer Inst 4: 47-53

25. Snedecor GW, Cochran WG (1967) Statistical methods, 6th edn. The Iowa State University Press. Ames, Iowa USA

26. Rahier J, Wallon J, Loozen S, Lefevre A, Gepts W, Haot J (1983) The pancreatic polypeptide cells in the human pancreas: the effects of age and diabetes. J Clin Endocrinol Metab 56: 441-444

27. Seifert G (1984) Cystic fibrosis and haemochromatosis. In: Klöppel G, Heitz PU (eds) Pancreatic pathology. Churchill Livingstone, Edinburgh London Melbourne New York

28. Gepts W, De Mey J (1978) Islet cell survival determined by morphology. An immunocytochemical study of the islets of Langerhans in juvenile diabetes mellitus. Diabetes 27 [Suppl 1]: 251-261

29. Grace ND, Powell LW (1974) Iron storage disorders of the liver. Gastroenterology 64: 1257-1283

30. Saudek CD (1980) Diabetes and the diseases of iron excess. Secondary diabetes: the spectrum of the diabetic syndromes. Podolsky S, Viswanathan M (eds) Raven, New York

31. Rahier J, Fält K, Münterfering H, Becker K, Gepts W, Falkmer S (1984) The basic structural lesion of persistent neonatal hypoglycaemia with hyperinsulinism: deficiency of pancreatic D cells or hyperactivity of B cells? Diabetologia $26: 282-289$

32. Passa P, Luyckx AS, Carpentier JL, Lefebvre PJ, Canivet J (1977) Glucagon secretion in diabetic patients with idiopathic haemochromatosis. Diabetologia 13: 509-513

33. Nelson RL, Baldus WP, Rubenstein AH, Go VLW, Service FJ (1979) Pancreatic alpha-cell function in diabetic hemochromatotic subjects. J Clin Endocrinol Metab 49: 412-416

34. Gonvers JJ, Henchoz L, Hofstetter JR, Muller WA (1977) Etude de la sécrétion de glucagon chez des patients atteints d'hémochromatose. Schweiz Med Wochenschr 107: 1841-1842

Received: 24 June 1984

and in revised form: 24 November 1986

Dr. J. Rahier

Department of Pathology

University Hospital St. Luc

Avenue Hippocrate 10

B-1200 Brussels

Belgium 